Article

\title{
Combining Orchardgrass and Alfalfa: Effects of Forage Ratios on In Vitro Rumen Degradation and Fermentation Characteristics of Silage Compared with Hay
}

\author{
Zhulin Xue ${ }^{1}$, Nan Liu ${ }^{1}$, Yanlu Wang ${ }^{2}$, Hongjian Yang ${ }^{2} \oplus$, Yuqi Wei ${ }^{1}$, Philipe Moriel ${ }^{3}$, \\ Elizabeth Palmer ${ }^{3}$ and Yingjun Zhang ${ }^{1, *}$ \\ 1 Key Laboratory of Grasslands Management and Utilization, Ministry of Agriculture and Rural Affairs, \\ College of Grassland Science and Technology, China Agricultural University, Beijing 100193, China; \\ xzl2007.ok@163.com (Z.X.); liunan@cau.edu.cn (N.L.); weiyuqi91@126.com (Y.W.) \\ 2 State Key Laboratory of Animal Nutrition, College of Animal Science and Technology, China Agricultural \\ University, Beijing 100193, China; yanluwang@yeah.net (Y.W.); yang_hongjian@sina.com (H.Y.) \\ 3 IFAS-Range Cattle Research and Education Center, University of Florida, Gainesville, FL 32611, USA; \\ pmoriel@ufl.edu (P.M.); e.palmer@ufl.edu (E.P.) \\ * Correspondence: zhangyj@cau.edu.cn
}

Received: 9 December 2019; Accepted: 23 December 2019; Published: 28 December 2019

check for updates

Simple Summary: Forages are an essential portion of ruminant rations to maintain rumen function. Exploring how orchardgrass and alfalfa interact in the rumen is necessary to better understand their feed use potential as both hay and silage. This study evaluated in vitro rumen degradation, fermentation characteristics, and methane production responses to different forage ratios of alfalfa and orchardgrass. The results indicate that dry matter and organic matter degradability and methane production were greater for mixed silages compared to mixed hays. A forage ratio of 50:50 for orchardgrass and alfalfa favor the growth of rumen microorganisms without compromising nutrient digestion and rumen fermentation.

\begin{abstract}
This study aimed to investigate the effects of different forage ratios of orchardgrass (Dactylis glomerata) and alfalfa (Medicago sativa) on in vitro rumen degradation and fermentation characteristics. Orchardgrass and alfalfa were harvested separately and prepared as hay and silage mixtures at ratios of 100:0, 75:25, 50:50, 25:75, and 0:100 (w/w on a dry matter basis) and anaerobically incubated for $48 \mathrm{~h}$ with rumen fluid obtained from lactating dairy cows. Fermented residues and cultured fluids were used to determine nutrient degradability, fermentation parameters, and associative effect indices. Increasing the proportion of alfalfa in hay and silage mixtures quadratically increased in vitro organic matter disappearance (IVOMD, up $+5.14 \%$ ) and marginally decreased in vitro neutral detergent fiber disappearance (NDFD, down $-1.79 \%$ ). Meanwhile, increasing the proportion of alfalfa accelerated the rumen fermentation process (e.g., gas production) and remarkably enhanced the growth of rumen microbes as indicated by microbial protein production (MCP, $13.4 \%$ increase). Increments of rumen degradability and methane production were more pronounced in silage mixtures than hay mixtures. In combination, a forage ratio of 50:50 for orchardgrass and alfalfa is recommended for both hay and silage in order to improve the feed use potential in ruminants.
\end{abstract}

Keywords: forage quality; gas production; methane; ruminant 


\section{Introduction}

Orchardgrass (Dactylis glomerata) is one of the most productive cool-season grasses, fairly drought resistant, and is widely distributed in North America, Europe, and East Asia [1]. Previous studies noted that orchardgrass had greater nutritive value than other forages commonly used as feedstuff for livestock, such as bromegrass, tall fescue, and reed canarygrass [2,3]. However, dietary inclusion of orchardgrass hay and silage in steers and sheep should be around $60-75 \%$ to avoid negative effects on rumen fermentation $[4,5]$. Additionally, polyphenol oxidase activity in orchardgrass was able to decrease protein degradation and lipolysis during aerobic ensiling and rumen fermentation [6]. Alfalfa (Medicago sativa) has been shown to be rich in crude protein $(\mathrm{CP})$ as well as rapidly degradable protein in the rumen and high inclusion in the diet usually reduces nitrogen $(\mathrm{N})$ utilization and increases urine $\mathrm{N}$ excretion $[7,8]$. However, it is unclear whether a mixture of orchardgrass and alfalfa has the potential to optimize ruminal digestibility and fermentation characteristics through complementary effects of nutrients in the forages.

Digestive interactions may occur in the rumen when ruminants are fed grass-legume mixtures $[9,10]$ and these interactions are due to the diverse impacts on rumen digestion, fermentation, and metabolism efficiency [11]. Positive or negative interactions indicate that the response of ruminants to grass-legume mixtures is either greater or less than the arithmetical calculation obtained from using the responses for grass or legume alone. It would be helpful to determine the proportion of alfalfa at which maximal benefits can be reached in terms of rumen digestibility and fermentation efficiency in order to more precisely formulate rations [12].

The two most common preservation methods of forages, haymaking or ensiling, result in different nutritional compositions, which coincide with changes in ruminal digestibility and fermentation characteristics. For example, alfalfa preserved as hay has less effective protein degradability and digestibility than alfalfa silage, but replacement of alfalfa hay with alfalfa silage did not change ruminal volatile fatty acids (VFAs) or ammonia N $[13,14]$. Although some studies have separately evaluated the digestibility and fermentation characteristics of silage or hay mixtures $[15,16]$, digestion parameters of silage in comparison with hay mixtures have not been assessed.

The in vitro digestion and gas production method has been widely used to routinely evaluate the associative effects of basal and supplementary feeds with many combinations and is less expensive and time-consuming than in vivo trials [17]. We hypothesized that mixtures of orchardgrass and alfalfa at suitable ratios would increase rumen degradability and fermentation efficiency, while decreasing methane $\left(\mathrm{CH}_{4}\right)$ production compared to alfalfa or orchardgrass alone. Therefore, the objectives of this study were to (1) investigate the associative effects of orchardgrass and alfalfa mixtures on rumen degradation and fermentation characteristics and (2) compare ruminal degradation and fermentation characteristics of hay and silage mixtures.

\section{Materials and Methods}

\subsection{Experimental Site for Forage Planting}

The field component of our experiment was conducted in Dongchengfang County $\left(39^{\circ} 37^{\prime} \mathrm{N}\right.$, $115^{\circ} 51^{\prime}$ E) in Zhuozhou City of Hebei Province of China. In September 2014, orchardgrass (cv. Aba) and alfalfa (cv. WL534) were established as monocultures in 2 field plots $(21 \times 75 \mathrm{~m})$, each with three replicates. Sowing rate was $15 \mathrm{~kg} / \mathrm{ha}$ and row spacing was $15 \mathrm{~cm}$ for alfalfa and orchardgrass monocultures. Monocultures were grown under the same management practices, with weed-free conditions and no insect pests. The sward soil was a sandy loam with organic matter (OM) content of $13.8 \mathrm{~g} / \mathrm{kg}$, total $\mathrm{N}$ content of $0.850 \mathrm{~g} / \mathrm{kg}$, plant-available phosphorus (P) content of $15.42 \mathrm{mg} / \mathrm{kg}$, available potassium (K) content of $80.12 \mathrm{mg} / \mathrm{kg}$ and a $\mathrm{pH}$ of 7.80 . A total of $75 \mathrm{~kg} / \mathrm{ha} \mathrm{N}$ fertilizer was applied annually in the swards. 


\subsection{Hay and Silage Mixture Preparation}

Whole orchardgrass and alfalfa plants were harvested (second cutting) with a reaping hook from the field plots at the jointing and early bloom stages. Ten square areas $(1 \times 1 \mathrm{~m})$ in each field plot were randomly selected and plants were harvested at a stubble height of $5 \mathrm{~cm}$ above ground. The harvested fresh forage was weighed separately and recorded. Representative forage samples (approximately $1 \mathrm{~kg}$ ) from each square harvest were oven-dried at $65^{\circ} \mathrm{C}$ for $48 \mathrm{~h}$ to determine the dry matter (DM) yield and chemical composition. Based on the forage DM obtained from four annual harvests, the annual DM yields of orchardgrass and alfalfa averaged $1065 \mathrm{~g} / \mathrm{m}^{2}$ and $1480 \mathrm{~g} / \mathrm{m}^{2}$, respectively. The chemical composition of orchardgrass and alfalfa prior to hay making and ensiling was shown in Table 1. After the forage was harvested, representative samples (approximately $20 \mathrm{~kg}$ ) of each preservation method were divided equally into two subsamples. The first subsample, of both orchardgrass and alfalfa, was air-dried in the sun for $48 \mathrm{~h}$, oven-dried at $65^{\circ} \mathrm{C}$ for $48 \mathrm{~h}$, thoroughly mixed to obtain forage ratios of 100:0, 75:25, 50:50, 25:75, and 0:100 (orchardgrass: alfalfa, w/w), and five representative hay samples of each forage ratio were prepared. All of these hay samples were ground in a mill (FW100; Tianjin Taisite Instrument Co., Ltd., Tianjin, China) to pass through a $1.0 \mathrm{~mm}$ sieve and stored in plastic bags for chemical analysis and in vitro batch culturing.

The second subsample, of both orchardgrass and alfalfa, was sun-wilted for $2 \mathrm{~h}$ until the DM content increased to $400 \mathrm{~g} / \mathrm{kg}$ and was chopped into $2.5 \mathrm{~cm}$ pieces. A microwave oven (M1-L213B, Midea Group Co., Ltd., Foshan, China) was used for the rapid determination of DM content at regular intervals. The wilted forage samples were mixed at ratios of 100:0, 75:25, 50:50, 25:75, and 0:100 (orchardgrass: alfalfa, w/w) based on DM content and were packed into polyethylene silos (1 L capacity) until the total forage weight reached approximately $750 \mathrm{~g}$. Five silo replicates of each forage ratio were prepared, and all silos were sealed with screw lids and kept in the dark at approximately $25^{\circ} \mathrm{C}$. After 40 days of ensiling, a total of $20 \mathrm{~g}$ of each silage mixture was homogenized in a blender with $180 \mathrm{~mL}$ of distilled water for $1 \mathrm{~min}$. The samples were filtered through a four-layered cheesecloth to prepare the silage extract for determination of ensiling characteristics such as $\mathrm{pH}$, ammonia $\mathrm{N}$, and organic acids, including lactic acid, acetic acid, propionic acid, and butyric acid. Silage mixtures were then dried in a forced-air oven at $65^{\circ} \mathrm{C}$ for $48 \mathrm{~h}$ and ground in a mill to pass through a $1.0 \mathrm{~mm}$ sieve for subsequent analysis.

Table 1. Chemical composition of orchardgrass and alfalfa prior to hay making and ensiling based on dry matter $(\mathrm{g} / \mathrm{kg})$.

\begin{tabular}{ccc}
\hline Item & Orchardgrass & Alfalfa \\
\hline Dry matter & 260 & 268 \\
Crude protein & 167 & 214 \\
Neutral detergent fiber & 562 & 484 \\
Acid detergent fiber & 424 & 385 \\
Acid detergent lignin & 37.0 & 72.2 \\
Ash & 111 & 92.0 \\
Ether extract & 26.8 & 24.0 \\
Calcium & 7.04 & 14.1 \\
Phosphorus & 3.42 & 3.36 \\
Potassium & 33.6 & 27.8 \\
Magnesium & 3.72 & 3.16 \\
\hline
\end{tabular}




\subsection{Rumen Fluid Collection}

All experimental procedures used in this study were conducted in accordance with the Institutional Animal Care Committee of China Agricultural University (CAU20171014-1). Rumen fluid was collected from five rumen-cannulated (Type 2c; Bar Diamond Inc., Parma, ID, USA) lactating Holstein dairy cows with a live weight of $530 \pm 31.2 \mathrm{~kg}$. Cows were uniformly fed equal rations twice daily at 7:00 a.m. and 7:00 p.m. and provided free access to water. The ration contained $4.0 \mathrm{~kg} / \mathrm{day}$ of alfalfa hay, $3.5 \mathrm{~kg} / \mathrm{day}$ of maize silage and $5.5 \mathrm{~kg} /$ day of commercial concentrate with a net energy for lactation of $6.69 \mathrm{MJ} / \mathrm{kg}$ $\mathrm{DM}$ and a CP content of $160 \mathrm{~g} / \mathrm{kg}$. Fresh rumen contents (mix of liquid and solid) from different sites inside the rumen were withdrawn from all dairy cows $1 \mathrm{~h}$ before the morning feeding with a pair of rubber fabric tongs inserted through the rumen cannula to form one composite sample. The composite sample was squeezed through four layers of surgical gauze to obtain the rumen fluid. Rumen fluid was kept in a thermos flask pre-warmed at $39^{\circ} \mathrm{C}$ and immediately transferred to the laboratory. Rumen fluid from the five dairy cows was mixed in equal proportions kept at $39{ }^{\circ} \mathrm{C}$ and filled with carbon dioxide $\left(\mathrm{CO}_{2}\right)$ prior to in vitro inoculation.

\subsection{In Vitro Batch Culturing and Sample Collection}

Samples $(500 \mathrm{mg}$ ) of each forage ratio, of both the hay and silage mixtures, were transferred into $120 \mathrm{~mL}$ glass bottles with Hungate stoppers and screw caps, resulting in a total of 50 samples in glass bottles ( 5 forage ratios $\times 2$ preservation methods $\times 5$ fermentation bottles). Fifty $\mathrm{mL}$ of fresh buffer solution at a pH of 6.85 [18] and $25 \mathrm{~mL}$ of filtered rumen fluid were mixed in each bottle, which were all purged with nitrogen gas $\left(\mathrm{N}_{2}\right)$ to maintain anaerobic conditions. Thereafter, each bottle was connected to an automated trace gas recording instrument (AGRS-III) [19] to continuously record the cumulative gas production (GP). Five bottles without forage samples were incubated as blanks. Simultaneously, an additional 30 glass bottles ( 5 forage ratios $\times 2$ preservation methods $\times 3$ fermentation bottles) prepared in the same manner were separately connected to pre-emptied air bags that collected all of the fermentation gases for subsequent determination and calculation. Three fermentations without samples were also included as blanks. All bottles were incubated at $39{ }^{\circ} \mathrm{C}$ for $48 \mathrm{~h}$, and these batch cultures were repeated in 3 experimental runs. Two hundred and forty bottles (5 forage ratios $\times$ 2 preservation methods $\times 5$ fermentation bottles $\times 3$ experimental replicates +5 forage ratios $\times 2$ preservation methods $\times 3$ fermentation bottles $\times 3$ experimental replicates) plus 8 bottles in each replicate that were used as blanks (rumen fluid + buffer) were examined in this experiment.

After incubation, the remaining contents in each bottle were separately filtered through preweighed nylon bags $(8 \times 12 \mathrm{~cm}, 42 \mu \mathrm{m}$ pore size). The filtrate was sampled for the determination of ammonia $\mathrm{N}$, microbial protein production (MCP) and volatile fatty acids (VFAs). The nylon bags were thoroughly rinsed and dried at $65^{\circ} \mathrm{C}$ for $48 \mathrm{~h}$ to a constant weight (the difference between two consecutive weights was no more than $0.20 \mathrm{mg}$ per $\mathrm{g}$ ) to determine in vitro dry matter disappearance (IVDMD), in vitro organic matter disappearance (IVOMD), in vitro neutral detergent fiber disappearance (NDFD) and in vitro acid detergent fiber disappearance (ADFD) after the chemical analysis of residues remaining in the bags.

\subsection{Chemical Analysis}

Determination of DM, OM, ether extract (EE), CP, and calcium (Ca), K, and magnesium (Mg) followed the methods of the Association of Official Analytic Chemists (AOAC) [20]. Following the method of Van Soest et al. [21], the contents of neutral detergent fiber (NDF), acid detergent fiber $(\mathrm{ADF})$, and acid detergent lignin (ADL) were determined using a Fiber Analyzer (ANKOM Technology Corporation, Fairport, NY, USA) and expressed including residual ash. The concentrations of ammonia $\mathrm{N}$ and organic acids, including lactic acid, acetic acid, propionic acid, and butyric acid, in the silage extract were determined according to the method described by Li and Meng [22]. 
For each cultured fluid, the concentrations of ammonia N [23] and MCP [24] were determined. The determination of VFAs was conducted according to the method described by Cui et al. [25]. Briefly, the filtrate of each cultured fluid kept in polypropylene tubes $(10 \mathrm{~mL})$ was centrifuged at $3500 \times g$ for $15 \mathrm{~min}$ at $4{ }^{\circ} \mathrm{C}$ and $1.0 \mathrm{~mL}$ of the supernatant sample was mixed with $0.3 \mathrm{~mL}$ of $250 \mathrm{~g} / \mathrm{L}$ orthophosphoric acid solution into a polypropylene microtube for $30 \mathrm{~min}$. Thereafter, the mixture was cooled at $4{ }^{\circ} \mathrm{C}$ for $2 \mathrm{~h}$ and centrifuged at $15,000 \times \mathrm{g}$ for $10 \mathrm{~min}$ at $4{ }^{\circ} \mathrm{C}$. The supernatants were kept at $-20^{\circ} \mathrm{C}$ for later VFAs analysis. Methane, $\mathrm{CO}_{2}$, and hydrogen gas $\left(\mathrm{H}_{2}\right)$ produced per $\mathrm{kg} \mathrm{OM}$ digested were measured with a gas chromatograph according to the method described by Cui et al. [25].

\subsection{Calculations}

Flieg's score was calculated according to the method of Kilic [26], as shown in Equation (1).

$$
\text { Flieg's score }=220+(2 \times \% \mathrm{DM}-15)-40 \times \mathrm{pH}
$$

The values at 81-100, 61-80, 41-60, 21-40, and 0-20 represented a very good, good, medium, low and poor silage quality, respectively.

Relative forage quality (RFQ) was calculated according to the method of Moore and Undersander [27], as shown in Equation (2).

$$
\mathrm{RFQ}=\mathrm{DMI} \times \mathrm{TDN} / 1.32
$$

where DMI is dry matter intake (\% of body weight) and TDN is the total digestible nutrients (\% of DM). For the alfalfa and orchardgrass-alfalfa mixtures, TDN and DMI were determined according to the methods described by the NRC [28] and Mertens [29], respectively, with NDFD adjusted according to Oba and Allen [30]. For orchardgrass, TDN and DMI were calculated following the methods of Moore and Undersander [27] and Moore and Kunkle [31], respectively.

Cumulative GP data $\left[\mathrm{GP}_{(\mathrm{t})}, \mathrm{mL} / \mathrm{g} \mathrm{DM}\right]$ at time $(\mathrm{t})$ were exported from the AGRS-III instrument into a Microsoft Excel file and fitted to a nonlinear model [32] by iterative regression analysis, as shown in Equation (3).

$$
\mathrm{GP}_{\mathrm{t}}=\mathrm{A} \times\left[1-\mathrm{e}^{-\mathrm{c} \times(\mathrm{t}-\mathrm{Lag})}\right]
$$

where A represents the asymptotic GP generated at a constant fractional rate (c) per unit time, $t$ is the time of the gas recording, $e$ is the base of the natural logarithm, and Lag represents the lag time before GP commences. The average GP rate (AGPR) at half of A was calculated according to the equation of García-Martínez et al. [33], as shown in Equation (4).

$$
\mathrm{AGPR}=\frac{\mathrm{A} \times \mathrm{c}}{2 \times(\mathrm{Ln} 2+\mathrm{c} \times \mathrm{Lag})},
$$

Single-factor associative effects index (SFAEI, \%) and multiple-factor associative effects index (MFAEI, \%) were calculated according to the methods described by Niderkorn et al. [34] and Wang [35], as shown in Equations (5)-(7).

$$
\text { SFAEI }=\frac{\text { observed value }- \text { calculated value }}{\text { calculated value }} \times 100
$$

Calculated value $=$ the measured value of sole orchardgrass $\times$ the proportion of orchardgrass in mixtures + the measured value of sole alfalfa $\times$ the proportion of alfalfa in mixtures

$$
\text { MFAEI }=\text { the sum of each sin gle }- \text { factor associative effect value , }
$$

In our current study, MFAEI is the sum of the six SFAEI of RFQ, OMD, NDFD, GP $48, c$, and MCP. 


\subsection{Statistical Analysis}

Data were analyzed using a randomized complete block design with two preservation methods (hay vs. silage) and five orchardgrass to alfalfa ratios (100:0, 75:25, 50:50, 25:75, and 0:100) for each block. One-way ANOVA was used to determine the linear and quadratic responses to the proportion of alfalfa inclusion on chemical composition and ensiling characteristics of the hay and the silage mixtures, respectively. The in vitro experimental data consisted of five fermentation replicates per forage mixture sample in each of the three experimental runs, for a total of 150 observations of the mixed ratios and preservation methods treatments. After averaging fermentation replicates within an experimental run, the data of 30 observations were subjected to ANOVA using a general linear model in which the fixed effects of preservation methods and mixed ratios of orchardgrass to alfalfa were considered. All statistical analyses were performed using R software (version 3.2.3). The least squares means and standard error (SEM) were calculated, and orthogonal contrasts were performed to examine the linear and quadratic effects of the proportion of alfalfa in hay and silage mixtures. Significance was declared at $p<0.05$ unless otherwise noted.

\section{Results}

\subsection{Chemical Composition of Hay and Silage Mixtures}

Increasing the proportion of alfalfa increased the contents of $\mathrm{CP}, \mathrm{ADL}$, and $\mathrm{Ca}$ and decreased NDF, $\mathrm{ADF}$, ash, and $\mathrm{Mg}$ in both hay and silage mixtures (Figure 1). Crude protein, NDF, ADF, and ADL were greater in the hay vs. silage mixtures. The TDN, DMI, and RFQ showed a quadratic increase with increasing alfalfa proportions, and these values were reduced in the hay mixtures compared to the silage mixtures (Figure 1).
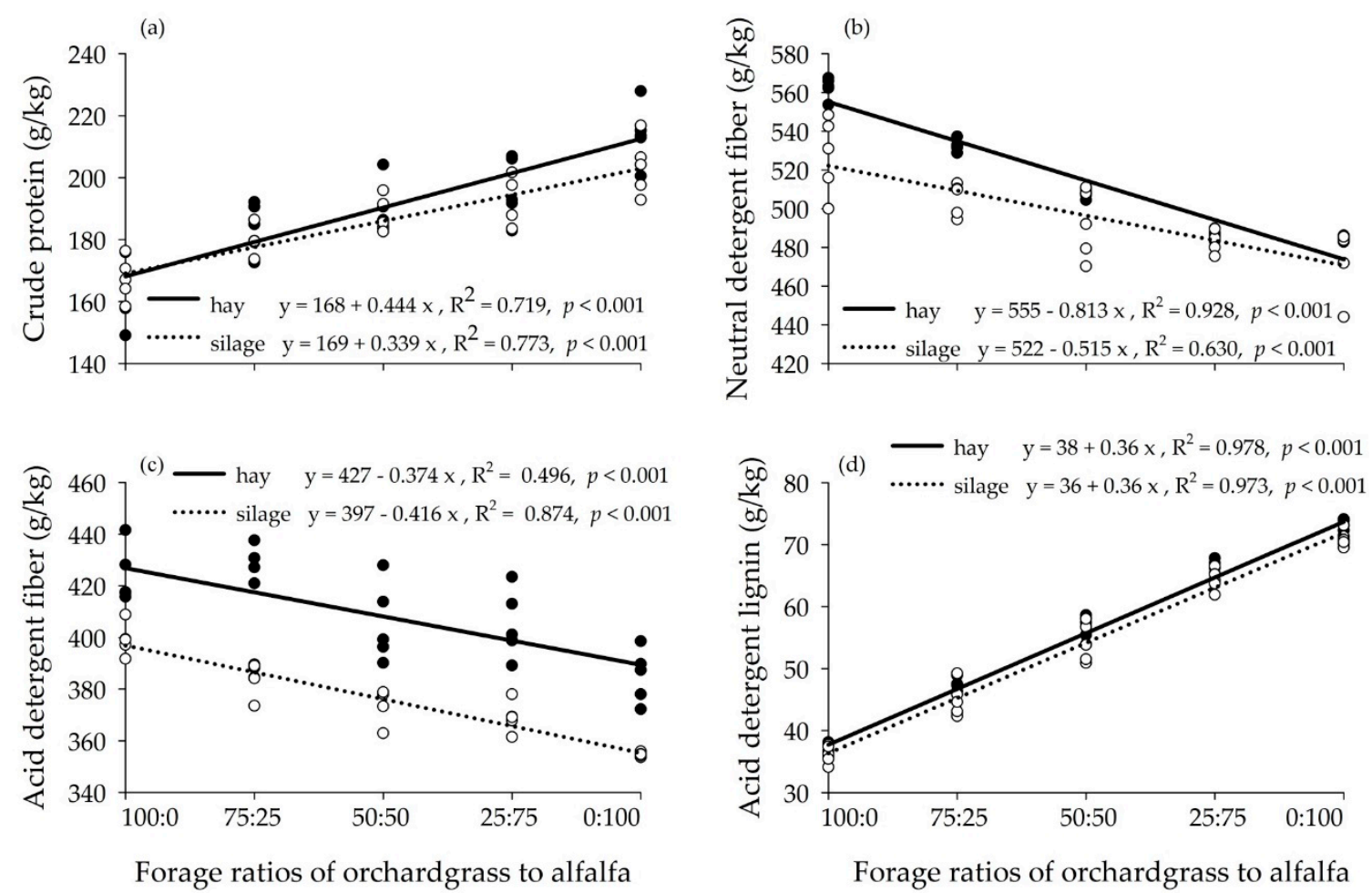

Forage ratios of orchardgrass to alfalfa

Figure 1. Cont. 

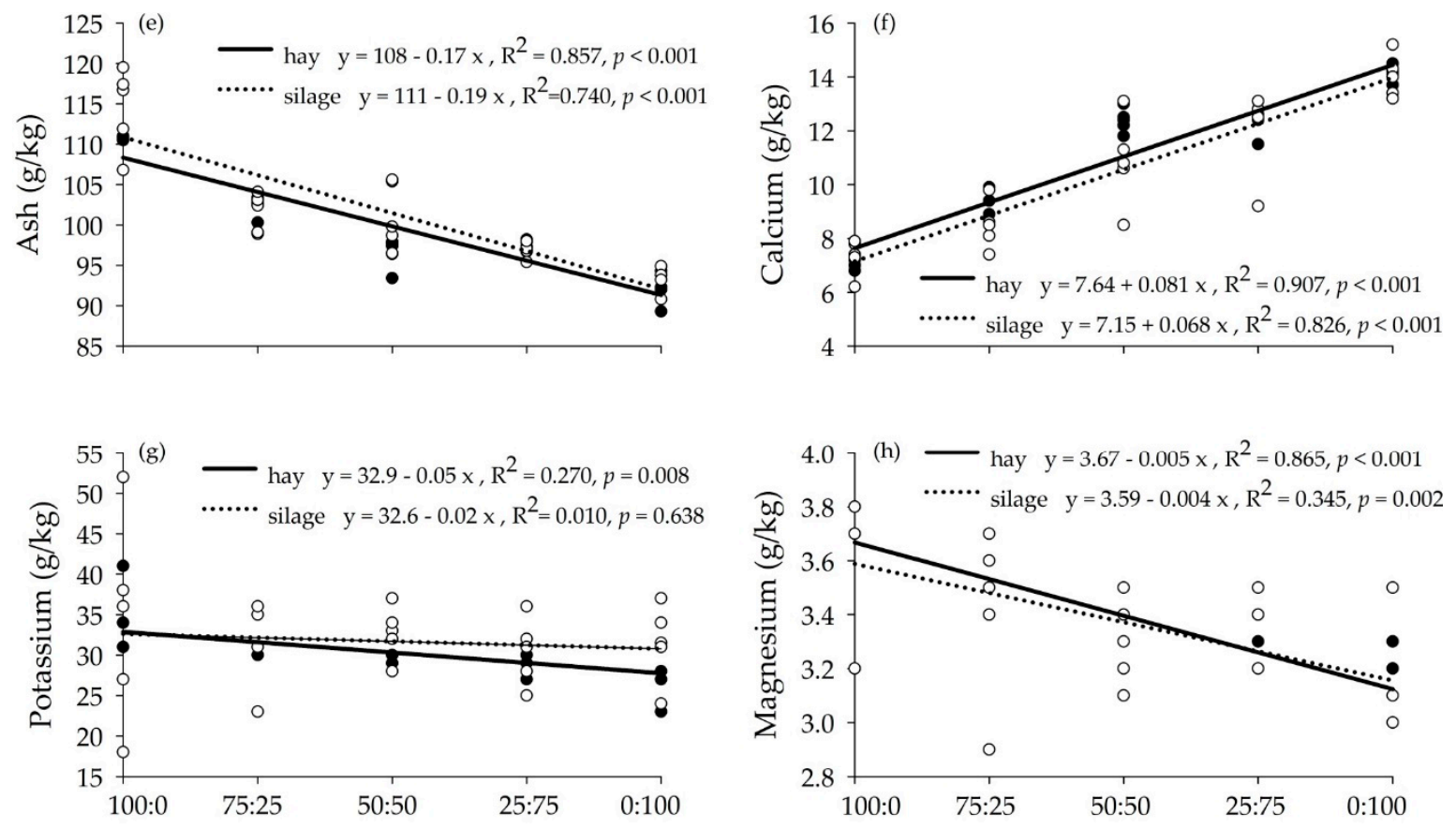

Forage ratios of orchardgrass to alfalfa
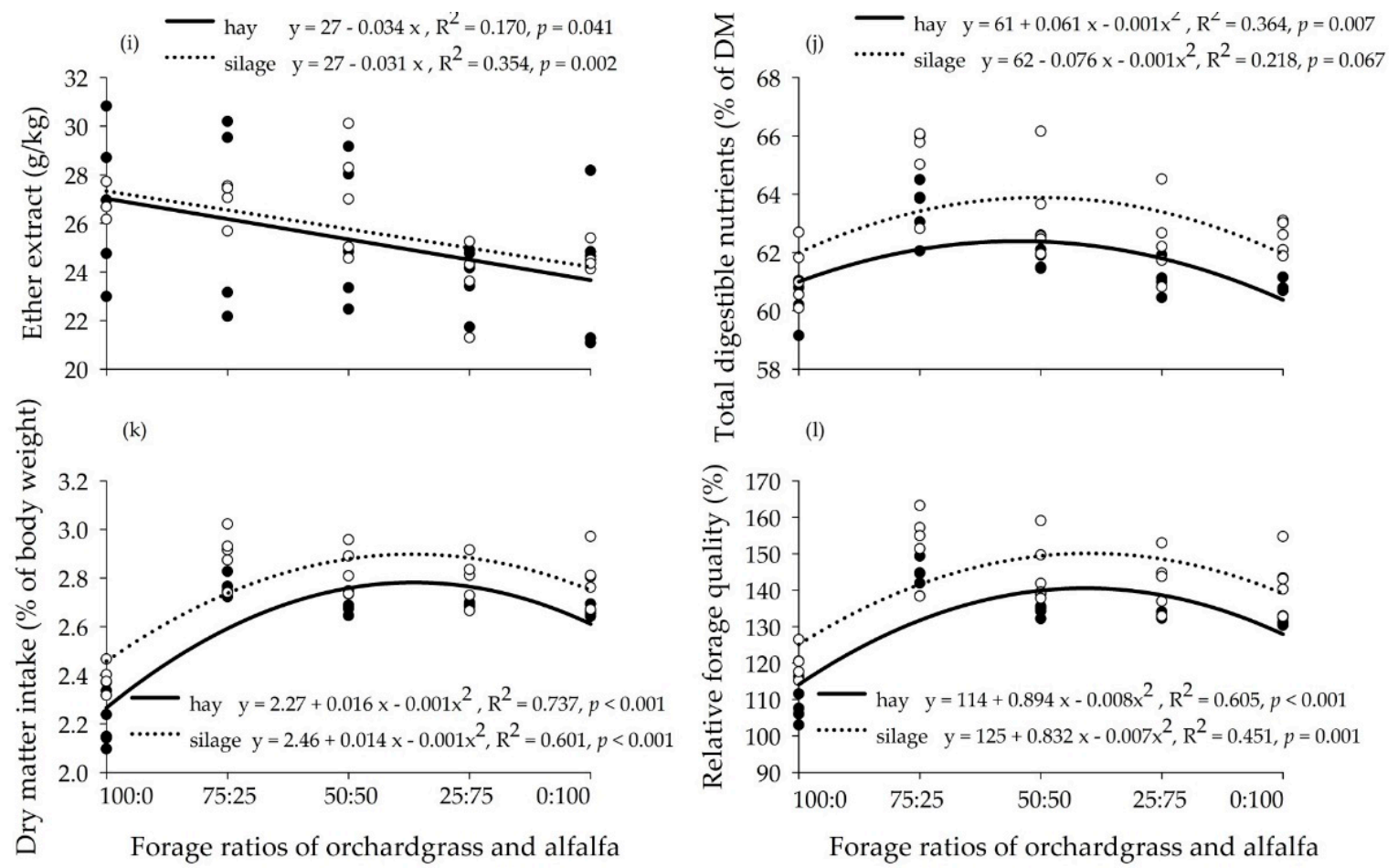

Figure 1. Chemical composition of orchardgrass and alfalfa mixtures preserved as hay and silage: (a) crude protein; (b) neutral detergent fiber; (c) acid detergent fiber; (d) acid detergent lignin; (e) ash; (f) calcium; (g) potassium; (h) magnesium; (i) ether extract; (j) total digestible nutrients; (k) dry matter intake; (l) relative forage quality.

\subsection{Ensiling Characteristics of Orchardgrass and Alfalfa Silage Mixtures}

The silage $\mathrm{pH}$ and the concentrations of ammonia $\mathrm{N}$ and acetic acid increased, whereas the concentration of lactic acid decreased as the proportion of alfalfa increased in silage mixtures (Table 2). The concentration of ammonia $\mathrm{N}$ in alfalfa was approximately twice that of orchardgrass $(11.1 \mathrm{mmol} / \mathrm{L}$ 
and $5.36 \mathrm{mmol} / \mathrm{L}$, respectively). However, the concentration of lactic acid in alfalfa was $355 \mathrm{mmol} / \mathrm{L}$ lower than that in orchardgrass (Table 2). According to the Flieg's scores for silage quality, mixtures of orchardgrass and alfalfa produced excellent quality silages when alfalfa proportion was $\leq 50 \%$ (Table 2). The silage mixtures of orchardgrass and alfalfa resulted in higher SFAEI of lactic acid and lower SFAEI of $\mathrm{pH}$, compared with the sole orchardgrass and alfalfa (Table 2).

Table 2. Ensiling characteristics of orchardgrass and alfalfa silage mixtures.

\begin{tabular}{|c|c|c|c|c|c|c|c|c|}
\hline \multirow{2}{*}{ Item } & \multicolumn{5}{|c|}{ Forage Ratios of Orchardgrass to Alfalfa } & \multirow{2}{*}{ SEM $^{2}$} & \multicolumn{2}{|c|}{$p^{3}$} \\
\hline & 100:0 & $75: 25$ & $50: 50$ & $25: 75$ & $0: 100$ & & Linear & Quadratic \\
\hline $\mathrm{pH}$ & 4.50 & 4.83 & 4.75 & 5.03 & 4.96 & 0.049 & $<0.001$ & $<0.001$ \\
\hline Ammonia $\mathrm{N}$ (mmol/L) & 5.36 & 7.96 & 9.96 & 11.2 & 11.1 & 0.585 & $<0.001$ & $<0.001$ \\
\hline Lactic acid (mmol/L) & 963 & 998 & 969 & 754 & 608 & 50.7 & 0.004 & 0.005 \\
\hline Acetic acid (mmol/L) & 1.58 & 2.55 & 7.54 & 7.88 & 8.63 & 0.860 & $<0.001$ & $<0.001$ \\
\hline Propionic acid (mmol/L) & 0.38 & 0.30 & 0.29 & 0.31 & 0.14 & 0.023 & 0.002 & 0.005 \\
\hline Butyric acid (mmol/L) & 0.12 & 0.10 & 0.13 & 0.14 & 0.15 & 0.008 & 0.081 & 0.159 \\
\hline Flieg's score $^{1}$ & 95.6 & 89.2 & 87.6 & 79.3 & 76.8 & 1.67 & $<0.001$ & $<0.001$ \\
\hline \multicolumn{9}{|c|}{ Single-factor associative effects indices (\%) of ensiling characteristics 4} \\
\hline $\mathrm{pH}$ & - & 4.6 & 0.5 & 3.8 & - & 0.76 & & \\
\hline Ammonia N (mmol/L) & - & 17.0 & 20.6 & 15.4 & - & 4.09 & & \\
\hline Lactic acid (mmol/L) & - & 14.2 & 23.4 & 8.2 & - & 5.76 & & \\
\hline Acetic acid (mmol/L) & - & -23.7 & 12.8 & 14.8 & - & 10.2 & & \\
\hline Propionic acid (mmol/L) & - & -6.4 & 11.0 & 51.1 & - & 11.93 & & \\
\hline
\end{tabular}

${ }^{1}$ Flieg's score was calculated by means of the $\mathrm{pH}$ values and DM contents of the silages: Flieg's score $=220+(2 \times \%$ $\mathrm{DM}-15)-40 \times \mathrm{pH}$. Flieg's score: < 20, very bad; 21-40, bad; 41-60, medium; 61-80, good; 81-100, very good. Since there was no difference on DM contents (ranging from $376 \mathrm{~g} / \mathrm{kg}$ to $383 \mathrm{~g} / \mathrm{kg}$ ) among silage mixtures, the data were not shown. ${ }^{2}$ SEM, standard error of the mean. ${ }^{3}$ Linear and quadratic represent the effects of alfalfa inclusion on different silage mixtures. ${ }^{4}$ Single-factor associative effects indices (SFAEI, \%) $=100 \times[$ (observed value - calculated value)/calculated value]. Calculated value was determined based on the proportional contribution of sole forage (orchardgrass vs. alfalfa) in the silage mixture. Positive or negative values indicated positive or negative associative effects of orchardgrass and alfalfa mixtures.

\subsection{Degradation Characteristics and Gas Production Kinetics of Hay and Silage Mixtures}

The IVDMD increased linearly (Figure 2a, $p<0.001$ ), whereas ADFD decreased linearly (Figure 2d, $p<0.001)$ with increasing proportions of alfalfa in hay and silage mixtures. Positive associative effects were observed on IVOMD (Figure $2 b, p<0.001$ ), cumulative $\mathrm{GP}_{48}$ (Table 3, $p<0.05$ ), and asymptotic GP (A) (Table 3, $p<0.05$ ); furthermore, the greatest values of these measurements were observed in the 50:50 orchardgrass-alfalfa mixtures. Negative associative effects on NDFD (Figure $2 c, p<0.05$ ) were observed when the proportion of alfalfa increased in hay and silage mixtures. The IVDMD (Figure $2 \mathrm{a}, p<0.001$ ) and IVOMD (Figure 2b, $p<0.05$ ) were greater in the silage mixtures than in the hay mixtures, but no effects of preservation method were observed for NDFD (Figure 2c), ADFD (Figure 2d), $\mathrm{GP}_{48}$ (Table 3) or other parameters of GP kinetics (Table 3). Positive associative effects were also observed for the fractional GP rate (c) and AGPR as the proportion of alfalfa increased in hay and silage mixtures $(p<0.05)$. Regarding fermentation end-product gases, no changes were observed in $\mathrm{CO}_{2}$ or $\mathrm{H}_{2}$ production; however, increasing the proportion of alfalfa linearly increased $\mathrm{CH}_{4}$ production $(p<0.05)$. Greater $\mathrm{CH}_{4}$ production was observed in the silage mixtures than in the hay mixtures $(p<0.05$; Table 3$)$. No interactions between forage ratios and preservation method were observed on degradation or gas production parameters $(p>0.05$; Table 3; Figure 2). 
(a)

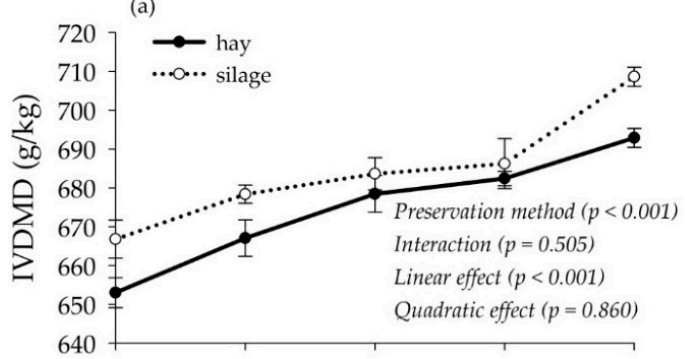

(c) $\rightarrow$ hay

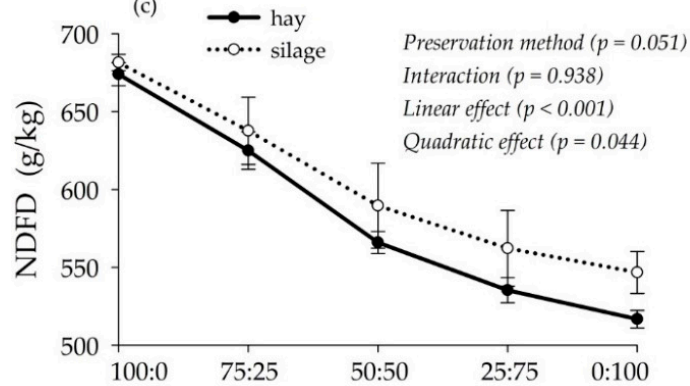

Forage ratios of orchardgrass to alfalfa (b)

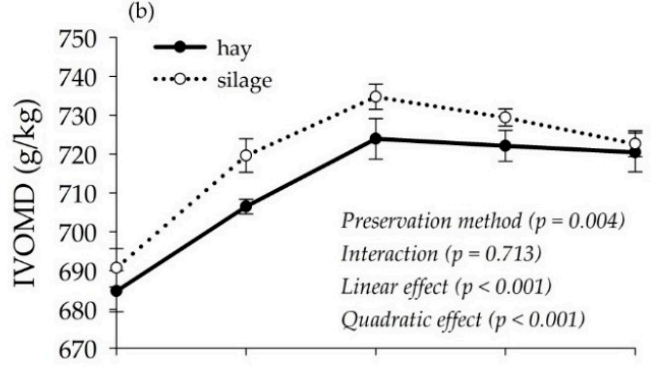

(d)

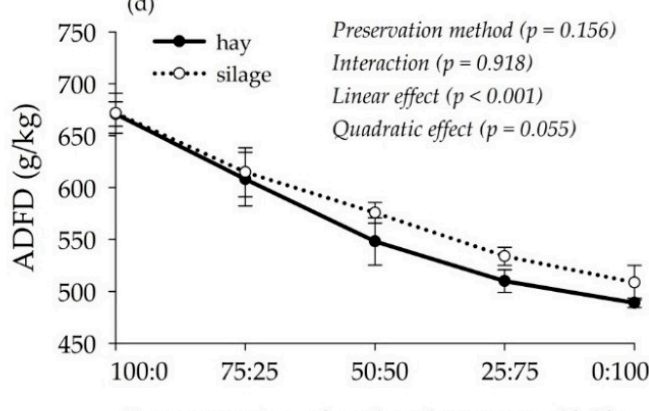

Forage ratios of orchardgrass to alfalfa

Figure 2. In vitro degradation characteristics of orchardgrass and alfalfa mixtures preserved as hay and silage: (a) IVDMD, in vitro dry matter disappearance; (b) IVOMD, in vitro organic matter disappearance; (c) NDFD, in vitro neutral detergent fiber disappearance; (d) ADFD, in vitro acid detergent fiber disappearance. The preservation method indicates whether the forage was preserved as hay or silage, and the interaction indicates the interaction between the preservation method and the ratio of orchardgrass to alfalfa. Orthogonal contrasts were used to examine the linear and quadratic effects of alfalfa inclusion on different hay and silage mixtures. Bars show the mean \pm standard error.

Table 3. Gas production kinetics of orchardgrass and alfalfa mixtures preserved as hay and silage.

\begin{tabular}{|c|c|c|c|c|c|c|c|c|c|c|}
\hline \multirow[b]{2}{*}{ Item $^{1}$} & \multirow{2}{*}{$\begin{array}{l}\text { Preservation } \\
\text { Method }\end{array}$} & \multicolumn{5}{|c|}{ Forage Ratios of Orchardgrass to Alfalfa } & \multirow[b]{2}{*}{ SEM $^{2}$} & \multicolumn{3}{|c|}{$p^{3}$} \\
\hline & & 100:0 & $75: 25$ & $50: 50$ & $25: 75$ & $0: 100$ & & $\begin{array}{l}\text { Preservation } \\
\text { Method }\end{array}$ & Linear & Quadratic \\
\hline $\mathrm{GP}_{48}(\mathrm{~mL} / \mathrm{g}$ & Hay & 122 & 128 & 133 & 134 & 131 & \multirow{2}{*}{1.1} & \multirow{2}{*}{0.847} & \multirow{2}{*}{$<0.001$} & \multirow{2}{*}{0.026} \\
\hline DM) & Silage & 124 & 124 & 136 & 134 & 134 & & & & \\
\hline \multicolumn{11}{|c|}{ GP kinetics } \\
\hline \multirow{2}{*}{$\mathrm{A}(\mathrm{mL} / \mathrm{g} \mathrm{DM})$} & Hay & 123 & 128 & 134 & 135 & 131 & \multirow[b]{2}{*}{1.1} & \multirow{2}{*}{0.837} & \multirow[b]{2}{*}{$<0.001$} & \multirow[b]{2}{*}{0.025} \\
\hline & Silage & 124 & 124 & 136 & 134 & 134 & & & & \\
\hline \multirow[b]{2}{*}{ c } & Hay & 0.13 & 0.14 & 0.16 & 0.16 & 0.15 & \multirow{2}{*}{0.002} & \multirow{2}{*}{0.165} & \multirow{2}{*}{0.011} & \multirow{2}{*}{0.004} \\
\hline & Silage & 0.13 & 0.14 & 0.16 & 0.14 & 0.14 & & & & \\
\hline \multirow{2}{*}{ Half-time (h) } & Hay & 2.71 & 2.69 & 2.55 & 2.60 & 2.60 & \multirow{2}{*}{0.012} & \multirow{2}{*}{0.339} & \multirow{2}{*}{0.005} & \multirow{2}{*}{0.005} \\
\hline & Silage & 2.72 & 2.66 & 2.57 & 2.65 & 2.65 & & & & \\
\hline \multirow{2}{*}{ AGPR (mL/h) } & Hay & 23.4 & 25.1 & 28.4 & 29.2 & 29.8 & \multirow{2}{*}{0.37} & \multirow{2}{*}{0.319} & \multirow{2}{*}{$<0.001$} & \multirow{2}{*}{0.025} \\
\hline & Silage & 24.2 & 24.1 & 28.4 & 28.5 & 29.1 & & & & \\
\hline \multicolumn{11}{|c|}{ Fermentation gas pattern (mL/g OM digested) } \\
\hline \multirow{2}{*}{$\mathrm{CO}_{2}$} & Hay & 174 & 176 & 178 & 180 & 176 & \multirow{2}{*}{0.8} & \multirow{2}{*}{0.081} & 0150 & 0675 \\
\hline & Silage & 176 & 166 & 178 & 175 & 177 & & & 0.150 & 0.675 \\
\hline & Hay & 31.6 & 34.5 & 36.2 & 36.4 & 37.1 & & & & \\
\hline $\mathrm{CH}_{4}$ & Silage & 34.6 & 37.5 & 37.8 & 39.0 & 39.2 & 0.62 & 0.045 & 0.006 & 0.287 \\
\hline $\mathrm{H}_{2}$ & Hay & 0.59 & 0.36 & 0.82 & 0.76 & 1.51 & & 0.476 & 0.513 & 0.164 \\
\hline $\mathrm{H}_{2}$ & Silage & 2.00 & 0.84 & 0.94 & 0.66 & 0.40 & 0.121 & 0.476 & 0.513 & 0.164 \\
\hline
\end{tabular}

${ }^{1} \mathrm{GP}_{48}$, cumulative gas production at $48 \mathrm{~h}$; A, asymptotic gas production; $\mathrm{c}$, fractional rate of the gas production of ' $\mathrm{A}$ '; half-time, the time when ' $\mathrm{A}$ ' reached its half-maximal value; AGPR, average gas production rate when half of 'A' occurred. ${ }^{2}$ SEM, standard error of the mean. ${ }^{3}$ The preservation method indicates whether the forage was preserved as hay or silage. Linear and quadratic represent the effects of alfalfa inclusion in the different hay and silage mixtures. Since there were no interactions between the preservation method and the ratios of orchardgrass to alfalfa, we did not present $p$-values on interaction in the Table 3. 


\subsection{Fermentation Characteristics of Hay and Silage Mixtures}

Concentration of ammonia $\mathrm{N}$ increased linearly $(p<0.05)$ when the proportion of alfalfa increased in hay and silage mixtures (Table 4). A positive associative effect on MCP was detected as the proportion of alfalfa increased $(p<0.05)$. No effects of alfalfa inclusion on the molar proportions of acetate, propionate, butyrate, and isobutyrate were observed $(p>0.05)$. However, the concentrations of total VFAs, valerate and isovalerate increased linearly with increasing alfalfa proportion $(p<0.05)$. No effects of preservation method were observed on these fermentation parameters $(p>0.05$; Table 4$)$. There were no interactions between forage ratios and preservation method on fermentation parameters $(p>0.05 ;$ Table 4$)$.

Table 4. Fermentation characteristics of orchardgrass and alfalfa mixtures preserved as hay and silage.

\begin{tabular}{|c|c|c|c|c|c|c|c|c|c|c|}
\hline \multirow[b]{2}{*}{ Item $^{1}$} & \multirow{2}{*}{$\begin{array}{l}\text { Preservation } \\
\text { Method }\end{array}$} & \multicolumn{5}{|c|}{ Forage Ratios of Orchardgrass to Alfalfa } & \multirow[b]{2}{*}{ SEM $^{2}$} & \multicolumn{3}{|c|}{$p^{3}$} \\
\hline & & 100:0 & $75: 25$ & $50: 50$ & 25:75 & $0: 100$ & & $\begin{array}{l}\text { Preservation } \\
\text { Method }\end{array}$ & Linear & Quadratic \\
\hline Ammonia & Hay & 20.0 & 20.0 & 20.4 & 21.5 & 21.5 & \multirow[b]{2}{*}{0.31} & \multirow{2}{*}{0.635} & \multirow{2}{*}{0.029} & \multirow[b]{2}{*}{0.996} \\
\hline $\mathrm{N}(\mathrm{mg} / \mathrm{dL})$ & Silage & 20.0 & 20.2 & 21.2 & 21.7 & 21.8 & & & & \\
\hline MCP & Hay & 270 & 276 & 329 & 345 & 338 & \multirow{2}{*}{5.2} & \multirow{2}{*}{0.555} & \multirow{2}{*}{$<0.001$} & \multirow[b]{2}{*}{0.034} \\
\hline$(\mu \mathrm{g} / \mathrm{mL})$ & Silage & 282 & 296 & 315 & 338 & 303 & & & & \\
\hline \multirow{2}{*}{$\begin{array}{l}\text { Total VFAs } \\
(\mathrm{mmol} / \mathrm{L})\end{array}$} & Hay & 110 & 116 & 118 & 117 & 120 & \multirow{2}{*}{1.2} & \multirow[b]{2}{*}{0.208} & \multirow[b]{2}{*}{0.049} & \multirow{2}{*}{0.688} \\
\hline & Silage & 113 & 110 & 115 & 110 & 119 & & & & \\
\hline \multicolumn{11}{|c|}{ VFA pattern $(\mathrm{mmol} / \mathrm{L})$} \\
\hline \multirow{2}{*}{ Acetate } & Hay & 71.2 & 76.6 & 78.4 & 77.4 & 77.8 & \multirow{2}{*}{1.10} & \multirow{2}{*}{0.085} & \multirow{2}{*}{0.309} & \multirow{2}{*}{0.809} \\
\hline & Silage & 74.5 & 70.1 & 72.6 & 68.8 & 76.2 & & & & \\
\hline \multirow{2}{*}{ Propionate } & Hay & 18.8 & 17.6 & 17.4 & 18.9 & 19.0 & \multirow{2}{*}{0.17} & \multirow{2}{*}{0.297} & \multirow{2}{*}{0.136} & \multirow{2}{*}{0.631} \\
\hline & Silage & 17.2 & 17.9 & 19.5 & 17.4 & 18.4 & & & & \\
\hline \multirow{2}{*}{ Butyrate } & Hay & 9.09 & 9.76 & 9.51 & 9.33 & 10.2 & \multirow{2}{*}{0.31} & \multirow{2}{*}{0.620} & \multirow{2}{*}{0.300} & \\
\hline & Silage & 9.45 & 9.56 & 9.82 & 10.3 & 10.4 & & & & 0.887 \\
\hline & Hay & 2.14 & 2.63 & 2.56 & 2.14 & 2.20 & & & & \\
\hline Isobutyrate & Silage & 2.36 & 2.34 & 2.64 & 2.63 & 2.83 & 0.084 & 0.257 & 0.900 & 0.811 \\
\hline Valerate & Hay & 2.61 & 3.02 & 3.10 & 2.81 & 3.50 & 0.093 & & & \\
\hline valerate & Silage & 2.80 & 2.88 & 2.94 & 3.25 & 3.40 & 0.093 & 0.801 & 0.015 & 0.710 \\
\hline Isovalerate & Hay & 6.04 & 6.20 & 6.68 & 6.54 & 7.16 & 0185 & 0.097 & 024 & \\
\hline Isovalerate & Silage & 6.60 & 6.76 & 7.18 & 7.23 & 7.99 & 0.185 & 0.097 & 0.024 & 0.704 \\
\hline
\end{tabular}

${ }^{1}$ Ammonia N, ammonia nitrogen; MCP, microbial protein production; VFAs, volatile fatty acids. ${ }^{2}$ SEM, standard error of the mean. ${ }^{3}$ The preservation method indicates whether the forage was preserved as hay or silage. Linear and quadratic represent the effects of alfalfa inclusion in different hay and silage mixtures. Since there were no interactions between the preservation method and the ratios of orchardgrass to alfalfa, we did not present $p$-values on interaction in the Table 4.

\subsection{SFAEI and MFAEI of Hay and Silage Mixtures}

The SFAEI of RFQ, IVOMD, c, MCP, and $\mathrm{GP}_{48}$ was positive in both hay and silage mixtures of orchardgrass and alfalfa (Figure 3). The SFAEI of RFQ was greatest at 75:25 orchardgrass to alfalfa hay and silage mixtures. Increasing the proportion of alfalfa increased the SFAEI of IVOMD, $\mathrm{GP}_{48}, \mathrm{c}$, and $\mathrm{MCP}$ by $+5.14 \%,+5.52 \%,+16.1 \%,+13.4 \%$, respectively, and decreased the SFAEI of NDFD $(-1.79 \%)$ when compared with the calculated value. Positive MFAEI was observed in all mixtures, and the highest MFAEI (up $+40 \%$ ) was observed in 50:50 of orchardgrass to alfalfa hay and silage mixtures. 


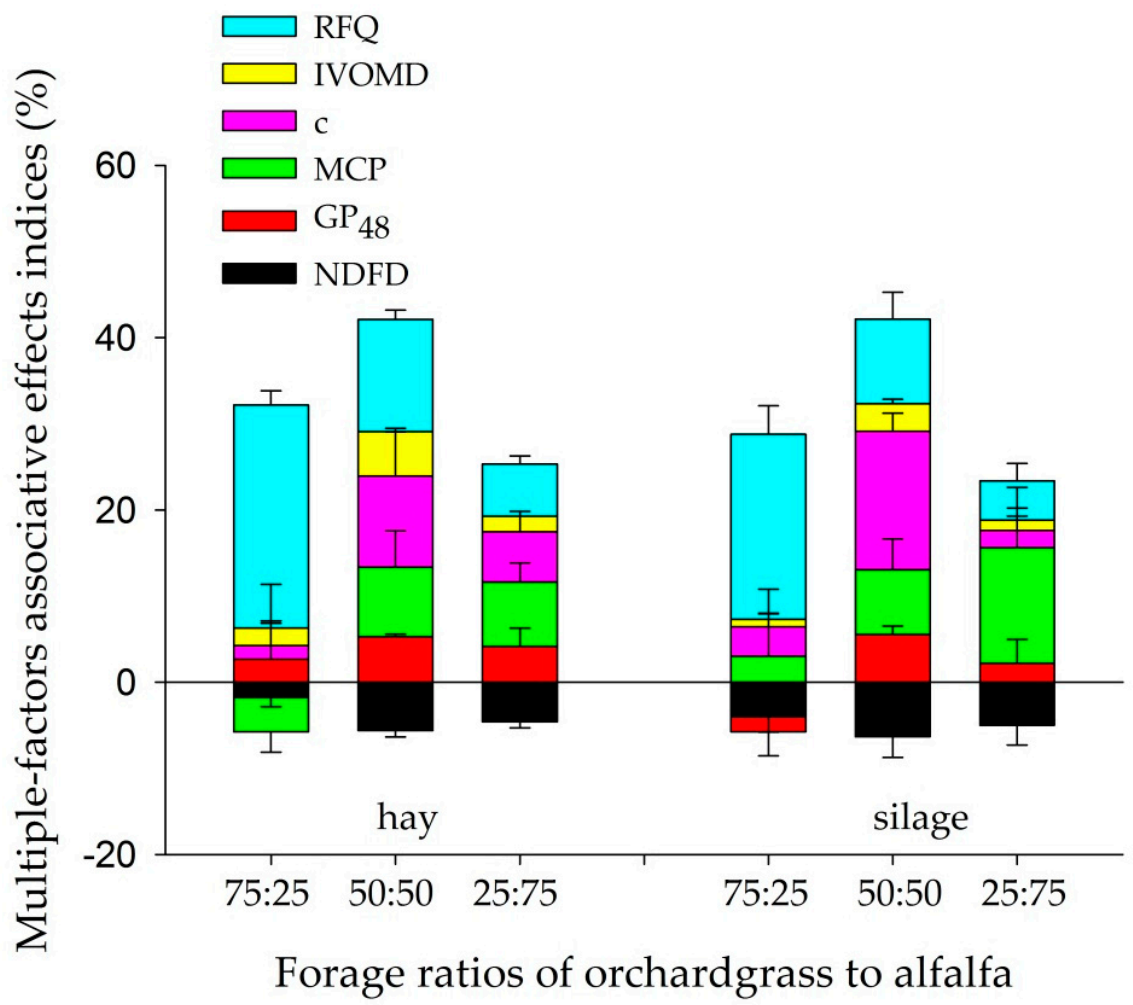

Figure 3. Single-factor associative effects indices (SFAEI, \%) and multiple-factors associative effects indices (MFAEI, \%) of hay and silage mixtures. RFQ, relative forage quality; IVOMD, in vitro dry matter disappearance; NDFD, in vitro neutral detergent fiber disappearance; c, gas production rate; $\mathrm{GP}_{48}$, gas production at $48 \mathrm{~h}$; $\mathrm{MCP}$, microbial protein production. Bars show the mean \pm standard error. Single-factor associative effects indices (SFAEI, \%) $=100 \times[$ (observed value - calculated value)/calculated value]. Calculated value was determined based on the proportional contribution of sole forage (orchardgrass vs. alfalfa) in the mixture. Positive or negative values indicated positive or negative associative effects of orchardgrass and alfalfa mixtures.

\section{Discussions}

As hypothesized, combining orchardgrass with alfalfa optimized the ruminal degradation and fermentation efficiency through complementary effects of nutrients in forage mixtures and the greatest MFAEI (up about $+40 \%$ ) was obtained at 50:50 of orchardgrass to alfalfa in both hay and silage mixtures. Although mixtures of orchardgrass and alfalfa decreased NDFD, this antagonistic effect was quite little for the total MFAEI, which presumably has been compensated for by synergistic effects of other nutrients. Considering the observed associative effects of mixing orchardgrass and alfalfa, it is possible to optimize forage use efficiency in ruminants.

\subsection{Chemical Composition of Hay and Silage Mixtures}

Greater $\mathrm{CP}$ and reduced NDF and ADF contents are usually observed in legumes compared to grasses, due to $\mathrm{N}$ fixation from the atmosphere and less cell wall material in legumes [36,37], similar to the current study. A reduction in $\mathrm{CP}, \mathrm{NDF}$, and ADF contents were observed in the silage mixtures than in the hay mixtures, probably because a smaller fraction of the protein was broken down into peptides, amino acids, and ammonia and some of the cellulose and hemicellulose were hydrolyzed during the ensiling process $[13,38]$. Greater values of RFQ were observed in alfalfa-containing mixtures compared with the orchardgrass alone, suggesting that alfalfa inclusion has the potential to improve the overall forage quality of mixtures and the subsequent animal performance $[39,40]$. 


\subsection{Ensiling Characteristics of Orchardgrass and Alfalfa Silage Mixtures}

Legumes are usually more difficult to preserve as silage than are grasses due to a reduction in water-soluble carbohydrates and a greater buffering capacity [7]. The results from the current study indicate that alfalfa silage had increased $\mathrm{pH}$ and ammonia $\mathrm{N}$ concentrations and decreased lactic acid concentrations compared to orchardgrass silage and silage mixtures of orchardgrass and alfalfa showed suitable ensiling characteristics and high associative effects indices. In accordance with previous studies [41,42], silage mixtures could be a feasible way to preserve nutrition and improve fermentation quality through the role of dominated Lactobacillus, compared with the sole silage crops.

\subsection{Associative Effects on the Degradation Characteristics and Gas Production Kinetics of Hay and Silage Mixtures}

The IVDMD linearly increased in response to increasing proportions of alfalfa in the present study due to its high CP and low fiber contents [43]. The IVDMD of silage mixtures was greater than that of hay mixtures, which agrees with previous results that the apparent digestibility of DM and OM in alfalfa silage was greater than that in alfalfa hay [44].

Negative associative effects on NDFD were detected as the proportion of alfalfa increased in mixtures, which is in agreement with other studies [10,45]. These results may be attributed to the antagonistic effects that occur in the fermentation extent and degradation rate of fiber fractions. Similarly, these antagonistic effects were more evident when the proportion of alfalfa was greater than $25 \%$ in alfalfa-Caucasian bluestem hay mixtures [46]. The dominant fibrolytic bacteria, that are not proteolytic, require $\mathrm{NH}_{3}$ and branched-chain VFAs that are usually derived from active proteolytic bacteria and amino acid fermentation bacteria that do not ferment carbohydrates [47,48]. The degradable and rapidly digested $\mathrm{N}$ from legumes compensated for the slow release of $\mathrm{N}$ from grasses and coincided with associations and shifts in the ruminal microbial community $[15,49]$ to better degrade the fiber fractions in grass-legume mixtures [46,50].

However, the NDF of legumes is more resistant to degrade than that of grasses because legumes have higher proportions of indigestible NDFs [51] with more complicated structures (e.g., cuticle sheets and vascular bundles) and physicochemical properties (e.g., alkali solubility and ether links), which limit the attachment of fibrolytic bacteria and the enzymatic hydrolysis of forage polysaccharides [37] and decrease the potential for fiber digestion [52]. In the current study, it appears that the positive effect of alfalfa inclusion on NDFD by supplying a rapidly digested $\mathrm{N}$ source for fibrolytic bacteria was offset by the negative effect of increased indigestible fiber fractions, subsequently decelerating the fermentation extent and degradation rate of NDF. High levels of fat, starch, and sugars that are rapidly fermented to VFAs can also reduce rumen $\mathrm{pH}$ and hence depress the activity of fibrolytic bacteria, decreasing NDFD [53-55].

The volume of GP was positively correlated with OM degradability, which is indirectly reflected in the potential of microbes to degrade feed and the extent of microbial fermentation [56]. The current results indicate positive associative effects on cumulative GP and IVOMD when the proportion of alfalfa increased in hay and silage mixtures, implying that complementary digestible nutrients in orchardgrass-alfalfa mixtures provided favorable substrates for microbes, resulting in improved fermentation. The presence of positive associative effects on the asymptotic fractional GP rate (c) but negative associative effects on the time to reach half of the asymptotic GP (half-time) suggests that the inclusion of alfalfa in mixtures accelerated microbial fermentation of digestible components and/or resulted in a shift in the site of digestion of cell contents, including $\mathrm{N}$ [9]. In summary, no differences were observed in IVDMD and IVOMD for either hay or silage mixtures containing 50, 75, or 100\% alfalfa, however, all mixtures at these proportions had greater IVDMD and IVOMD and reduced NDFD and ADFD values than did mixtures with $25 \%$ or $0 \%$ alfalfa. If the DM and OM degradability of a mixture needs to be increased, at least $50 \%$ alfalfa is required based on the results obtained in this study.

There was no effect on $\mathrm{CO}_{2}$ and $\mathrm{H}_{2}$ with increasing alfalfa proportions, this could be explained by similar responses in acetate, propionate, and butyrate [57]. The amount of $\mathrm{CH}_{4}$ produced per unit of 
OM digested increased linearly with increasing alfalfa proportion, and the higher nitrogen-free extract (NFE) $(44.07 \%$ vs. $43.75 \%)$ and lower crude fiber (CF) (21.0\% vs. $33.93 \%)$ in alfalfa compared with orchardgrass could explain the comparatively high $\mathrm{CH}_{4}$ production with alfalfa [58,59]. Feedstuffs with higher GP and IVDMD tended to have greater $\mathrm{CH}_{4}$ production [60]; this trend is in accordance with the current study where silage mixtures, which had greater IVDMD and IVOMD, had increased $\mathrm{CH}_{4}$ production per gram of $\mathrm{OM}$ digested than did the hay mixtures.

\subsection{Associative Effects on the Fermentation Characteristics of Hay and Silage Mixtures}

Ammonia N showed a linear increase in cultured fluids as the proportion of alfalfa increased, which was partially due to the proteolysis in alfalfa that occurred during in vitro incubation [61]. Rumen fermentation and microbial protein synthesis proceeded at a lower than maximal rate when the concentrations of ammonia $\mathrm{N}$ in the rumen fluid were less than $23.5 \mathrm{mg} / \mathrm{dL}$ and $5 \mathrm{mg} / \mathrm{dL}$, respectively $[62,63]$. In the current study, the concentration of ammonia $\mathrm{N}$ in the cultured fluid was above the requirements to maximize MCP synthesis ( $>5 \mathrm{mg} / \mathrm{dL}$ ) and thus the sufficient energy should match the synthetic abilities of microorganisms to effectively utilize these $\mathrm{N}$ resources [64]. Positive associative effects on MCP were observed as the proportion of alfalfa increased in our study, implying that mixtures of orchardgrass and alfalfa contributed more to the balance of readily degradable carbohydrates and readily degradable protein than did the monocultures, subsequently improving microbial protein synthesis and increasing bacterial $\mathrm{N}$ flow and microbial growth.

The concentration of total VFAs linearly increased with increasing proportions of alfalfa, and similarly, increased VFAs production was also observed in sweet sorghum-alfalfa mixtures [15]. In our study, alfalfa inclusion did not change the molar proportions of acetate, propionate, and butyrate, probably because the ruminal microbial community and metabolic pathways by which specific microbes utilize substrates to produce VFAs end-products were not altered [65]. The concentrations of valerate and isovalerate increased linearly with increasing alfalfa proportions, which was in accordance with a previous study [17] showing that the CP level was significantly correlated with valerate and isovalerate production.

\section{Conclusions}

The forage ratio of 50:50 for orchardgrass and alfalfa hay and silage mixtures favored the growth of rumen microorganisms and improved nutrient digestion and ruminal fermentability. Increments of rumen degradability and methane production were more pronounced in silage mixtures than hay mixtures. This study provided potential evidence on how to maximize forage use efficiency in ruminant systems, and further research could be performed to assess the synergistic effects of this practice on agronomic characteristics and ruminant production performance.

Author Contributions: Conceptualization, Z.X. and Y.Z.; Methodology, Z.X., Y.Z. and H.Y.; Formal analysis, Z.X. and Y.Z.; Investigation, Y.W. (Yanlu Wang) and Y.W. (Yuqi Wei). Data curation, Z.X. and Y.Z.; Writing-original draft preparation, Z.X.; Writing—review and editing, N.L., H.Y., P.M., E.P. and Y.Z.; Supervision, Y.Z.; Project administration, Y.Z.; Funding acquisition, Y.Z. All authors have read and agreed to the published version of the manuscript.

Funding: This study was funded by the China Forage and Grass Research System (CARS-34).

Conflicts of Interest: The authors declare no conflict of interest.

\section{References}

1. Stewart, A.V.; Ellison, N.W. Dactylis. In Wild Crop Relatives: Genomic and Breeding Resources; Kole, C., Ed.; Springer: Berlin/Heidelberg, Germany, 2011; pp. 73-87.

2. Turner, L.; Donaghy, D.; Lane, P.; Rawnsley, R. A comparison of the establishment, productivity, and feed quality of four cocksfoot (Dactylis glomerata L.) and four brome (Bromus spp.) cultivars, under leaf stage based defoliation management. Aust. J. Agric. Res. 2007, 58, 900-906. [CrossRef] 
3. Butkutè, B.; Lemežienè, N.; Kanapeckas, J.; Navickas, K.; Dabkevičius, Z.; Venslauskas, K. Cocksfoot, tall fescue and reed canary grass: Dry matter yield, chemical composition and biomass convertibility to methane. Biomass Bioenergy 2014, 66, 1-11. [CrossRef]

4. Bourquin, L.D.; Titgemeyer, E.C.; Merchen, N.R.; Fahey, G.C. Forage level and particle size effects on orchardgrass digestion by steers.1. Site and extent of organic matter, nitrogen, and cell wall digestion. J. Anim. Sci. 1994, 72, 746. [CrossRef] [PubMed]

5. Niderkorn, V.; Martin, C.; Rochette, Y.; Julien, S.; Baumont, R. Associative effects between orchardgrass and red clover silages on voluntary intake and digestion in sheep: Evidence of a synergy on digestible dry matter intake. J. Anim. Sci. 2015, 93, 4967-4976. [CrossRef] [PubMed]

6. Lee, M.R.; Olmos Colmenero, J.D.J.; Winters, A.L.; Scollan, N.D.; Minchin, F.R. Polyphenol oxidase activity in grass and its effect on plant-mediated lipolysis and proteolysis of Dactylis glomerata (cocksfoot) in a simulated rumen environment. J. Sci. Food Agric. 2006, 86, 1503-1511. [CrossRef]

7. Phelan, P.; Moloney, A.P.; McGeough, E.J.; Humphreys, J.; Bertilsson, J.; O’Riordan, E.G.; O’Kiely, P. Forage Legumes for Grazing and Conserving in Ruminant Production Systems. Crit. Rev. Plant Sci. 2015, 34, 281-326. [CrossRef]

8. Peyraud, J.; Astigarraga, L. Review of the effect of nitrogen fertilization on the chemical composition, intake, digestion and nutritive value of fresh herbage: Consequences on animal nutrition and $\mathrm{N}$ balance. Anim. Feed Sci. Technol. 1998, 72, 235-259. [CrossRef]

9. Patra, A. Effects of supplementing low-quality roughages with tree foliages on digestibility, nitrogen utilization and rumen characteristics in sheep: A meta-analysis. J. Anim. Physiol. Anim. Nutr. 2010, 94, 338-353. [CrossRef]

10. Johansen, M.; Søegaard, K.; Lund, P.; Weisbjerg, M.R. Digestibility and clover proportion determine milk production when silages of different grass and clover species are fed to dairy cows. J. Dairy Sci. 2017, 100, 8861-8880. [CrossRef]

11. INRA. INRA Feeding System for Ruminants; Wageningen Academic Publishers: Wageningen, The Netherlands, 2018; pp. 44-59.

12. Niderkorn, V.; Martin, C.; Bernard, M.; Le Morvan, A.; Rochette, Y.; Baumont, R. Effect of increasing the proportion of chicory in forage-based diets on intake and digestion by sheep. Animal 2019, 13, 718-726. [CrossRef]

13. Hristov, A.N.; Sandev, S.G. Proteolysis and rumen degradability of protein in alfalfa preserved as silage, wilted silage or hay. Anim. Feed Sci. Technol. 1998, 72, 175-181. [CrossRef]

14. Plaizier, J.C. Replacing chopped alfalfa hay with alfalfa silage in barley grain and alfalfa-based total mixed rations for lactating dairy cows. J. Dairy Sci. 2004, 87, 2495-2505. [CrossRef]

15. Chen, L.; Dong, Z.; Li, J.; Shao, T. Ensiling characteristics, in vitro rumen fermentation, microbial communities and aerobic stability of low-dry matter silages produced with sweet sorghum and alfalfa mixtures. J. Sci. Food Agric. 2019, 99, 2140-2151. [CrossRef]

16. Dal Pizzol, J.; Ribeiro-Filho, H.; Quereuil, A.; Le Morvan, A.; Niderkorn, V. Complementarities between grasses and forage legumes from temperate and subtropical areas on in vitro rumen fermentation characteristics. Anim. Feed Sci. Technol. 2017, 228, 178-185. [CrossRef]

17. Getachew, G.; Robinson, P.; DePeters, E.; Taylor, S. Relationships between chemical composition, dry matter degradation and in vitro gas production of several ruminant feeds. Anim. Feed Sci. Technol. 2004, 111, 57-71. [CrossRef]

18. Menke, K.H.; Steingass, H. Estimation of the energetic feed value obtained from chemical analysis and in vitro gas production using rumen fluid. Anim. Res. Dev. 1988, 28, 7-55.

19. Zhang, D.; Yang, H. In vitro ruminal methanogenesis of a hay-rich substrate in response to different combination supplements of nitrocompounds; pyromellitic diimide and 2-bromoethanesulphonate. Anim. Feed Sci. Technol. 2011, 163, 20-32. [CrossRef]

20. AOAC. Official Methods of Analysis of AOAC International, 17th ed.; Association of Official Analytical Chemists: Gaithersburg, MD, USA, 2005.

21. Van Soest, P.J.; Robertson, J.B.; Lewis, B.A. Methods for dietary fiber, neutral detergent fiber, and nonstarch polysaccharides in relation to animal nutrition. J. Dairy Sci. 1991, 74, 3583-3597. [CrossRef]

22. Li, Y.; Meng, Q. Effect of different types of fibre supplemented with sunflower oil on ruminal fermentation and production of conjugated linoleic acids in vitro. Arch. Anim. Nutr. 2006, 60, 402-411. [CrossRef] 
23. Verdouw, H.; Vanechteld, C.J.A.; Dekkers, E.M.J. Ammonia determination based on indophenol formation with sodium salicylate. Water Res. 1978, 12, 399-402. [CrossRef]

24. Makkar, H.; Sharma, O.; Dawra, R.; Negi, S. Simple determination of microbial protein in rumen liquor. J. Dairy Sci. 1982, 65, 2170-2173. [CrossRef]

25. Cui, J.; Yang, H.; Yu, C.; Bai, S.; Wu, T.; Song, S.; Sun, W.; Shao, X.; Jiang, L. Effect of urea fertilization on biomass yield, chemical composition, in vitro rumen digestibility and fermentation characteristics of straw of highland barley planted in Tibet. J. Agric. Sci. 2016, 154, 151-164. [CrossRef]

26. Kilic, A. Silo Feed (Instruction, Education and Application Proposals); Bilgehan Press: Izmir, Turkey, 1986.

27. Moore, J.E.; Undersander, D.J. Relative forage quality: An alternative to relative feed value and quality index. In Proceedings of the 13th Annual Florida Ruminant Nutrition Symposium, Gainesville, FL, USA, 10-11 January 2002.

28. National Research Council. Nutrient Requirements of Dairy Cattle; National Academies Press: Washington, DC, USA, 2001.

29. Mertens, D. Predicting intake and digestibility using mathematical models of ruminal function. J. Anim. Sci. 1987, 64, 1548-1558. [CrossRef] [PubMed]

30. Oba, M.; Allen, M. Evaluation of the importance of the digestibility of neutral detergent fiber from forage: Effects on dry matter intake and milk yield of dairy cows. J. Dairy Sci. 1999, 82, 589-596. [CrossRef]

31. Moore, J.; Kunkle, W. Evaluation of equations for estimating voluntary intake of forages and forage-based diets. J. Anim. Sci. 1999, 1, 204.

32. France, J.; Dijkstra, J.; Dhanoa, M.; Lopez, S.; Bannink, A. Estimating the extent of degradation of ruminant feeds from a description of their gas production profiles observed in vitro: Derivation of models and other mathematical considerations. Br. J. Nutr. 2000, 83, 143-150. [CrossRef] [PubMed]

33. García-Martínez, R.; Ranilla, M.; Tejido, M.; Carro, M. Effects of disodium fumarate on in vitro rumen microbial growth, methane production and fermentation of diets differing in their forage: Concentrate ratio. Br. J. Nutr. 2005, 94, 71-77. [CrossRef]

34. Niderkorn, V.; Baumont, R.; Le Morvan, A.; Macheboeuf, D. Occurrence of associative effects between grasses and legumes in binary mixtures on in vitro rumen fermentation characteristics. J. Anim. Sci. 2011, 89, 1138-1145. [CrossRef]

35. Wang, J. Methods in Ruminant Nutrition Research; Modern Education Press: Beijing, China, 2011. (In Chinese)

36. Krawutschke, M.; Kleen, J.; Weiher, N.; Loges, R.; Taube, F.; Gierus, M. Changes in crude protein fractions of forage legumes during the spring growth and summer regrowth period. J. Agric. Sci. 2013, 151, 72-90. [CrossRef]

37. Buxton, D.R.; Redfearn, D.D. Plant limitations to fiber digestion and utilization. J. Nutr. 1997, 127, 814S-818S. [CrossRef]

38. Kondo, M.; Shimizu, K.; Jayanegara, A.; Mishima, T.; Matsui, H.; Karita, S.; Goto, M.; Fujihara, T. Changes in nutrient composition and in vitro ruminal fermentation of total mixed ration silage stored at different temperatures and periods. J. Sci. Food Agric. 2016, 96, 1175-1180. [CrossRef] [PubMed]

39. Salama, H.S.A.; Zeid, M.M.K. Hay quality evaluation of summer grass and legume forage monocultures and mixtures grown under irrigated conditions. Aust. J. Crop Sci. 2016, 11, 1543. [CrossRef]

40. Favre, J.R.; Castiblanco, T.M.; Combs, D.K.; Wattiaux, M.A.; Picasso, V.D. Forage nutritive value and predicted fiber digestibility of Kernza intermediate wheatgrass in monoculture and in mixture with red clover during the first production year. Anim. Feed Sci. Technol. 2019, 258, 114298. [CrossRef]

41. Wang, M.; Wang, L.; Yu, Z. Fermentation dynamics and bacterial diversity of mixed lucerne and sweet corn stalk silage ensiled at six ratios. Grass Forage Sci. 2019, 74, 264-273. [CrossRef]

42. Ni, K.; Zhao, J.; Zhu, B.; Su, R.; Pan, Y.; Ma, J.; Zhou, G.; Tao, Y.; Liu, X.; Zhong, J. Assessing the fermentation quality and microbial community of the mixed silage of forage soybean with crop corn or sorghum. Bioresour. Technol. 2018, 265, 563-567. [CrossRef] [PubMed]

43. Jung, H.G.; Allen, M.S. Characteristics of plant-cell walls affecting intake and digestibility of forages by ruminants. J. Anim. Sci. 1995, 73, 2774-2790. [CrossRef]

44. Hristov, A.N.; Broderick, G.A. Synthesis of microbial protein in ruminally cannulated cows fed alfalfa silage, alfalfa hay, or corn silage. J. Dairy Sci. 1996, 79, 1627-1637. [CrossRef]

45. Reid, R.L.; Templeton, W.C., Jr.; Ranney, T.S.; Thayne, W.V. Digestibility, intake and mineral utilization of combinations of grasses and legumes by lambs. J. Anim. Sci. 1987, 64, 1725-1734. [CrossRef] 
46. Bowman, J.; Asplund, J. Evaluation of mixed lucerne and caucasian bluestem hay diets fed to sheep. Anim. Feed Sci. Technol. 1988, 20, 19-31. [CrossRef]

47. Hobson, P.N.; Stewart, C.S. The Rumen Microbial Ecosystem, 2nd ed.; Blackie Academic \& Professional: London, UK, 1997.

48. Millen, D.D.; Arrigoni, M.D.B.; Pacheco, R.D.L. Rumenology, 1st ed.; Springer International Publishing: Cham, Switzerland, 2016.

49. Liu, J.; Zhang, M.; Xue, C.; Zhu, W.; Mao, S. Characterization and comparison of the temporal dynamics of ruminal bacterial microbiota colonizing rice straw and alfalfa hay within ruminants. J. Dairy Sci. 2016, 99, 9668-9681. [CrossRef]

50. Kammes, K.L.; Allen, M.S. Nutrient demand interacts with forage family to affect digestion responses in dairy cows. J. Dairy Sci. 2012, 95, 3269-3287. [CrossRef] [PubMed]

51. Bhatti, S.A.; Bowman, J.G.P.; Firkins, J.L.; Grove, A.V.; Hunt, C.W. Effect of intake level and alfalfa substitution for grass hay on ruminal kinetics of fiber digestion and particle passage in beef cattle. J. Anim. Sci. 2008, 86, 134-145. [CrossRef] [PubMed]

52. Van Soest, P.J. Nutritional Ecology of the Ruminant, 2nd ed.; Cornell University press: Ithaca, NY, USA, 1994.

53. Chen, K.J.; Jan, D.F.; Chiou, P.W.S.; Yang, D.W. Effects of dietary heat extruded soybean meal and protected fat supplement on the production, blood and ruminal characteristics of Holstein cows. Asian-Australas. J. Anim. Sci. 2002, 15, 821-827. [CrossRef]

54. Brask, M.; Lund, P.; Hellwing, A.L.F.; Poulsen, M.; Weisbjerg, M.R. Enteric methane production, digestibility and rumen fermentation in dairy cows fed different forages with and without rapeseed fat supplementation. Anim. Feed Sci. Technol. 2013, 184, 67-79. [CrossRef]

55. Oba, M.; Mewis, J.L.; Zhining, Z. Effects of ruminal doses of sucrose, lactose, and corn starch on ruminal fermentation and expression of genes in ruminal epithelial cells. J. Dairy Sci. 2015, 98, 586-594. [CrossRef]

56. Menke, K.; Raab, L.; Salewski, A.; Steingass, H.; Fritz, D.; Schneider, W. The estimation of the digestibility and metabolizable energy content of ruminant feedingstuffs from the gas production when they are incubated with rumen liquor in vitro. J. Agric. Sci. 1979, 93, 217-222. [CrossRef]

57. Pen, B.; Sar, C.; Mwenya, B.; Kuwaki, K.; Morikawa, R.; Takahashi, J. Effects of Yucca schidigera and Quillaja saponaria extracts on in vitro ruminal fermentation and methane emission. Anim. Feed Sci. Technol. 2006, 129, 175-186. [CrossRef]

58. Lee, H.; Lee, S.; Kim, J.; Oh, Y.; Kim, B.; Kim, C.; Kim, K. Methane production potential of feed ingredients as measured by in vitro gas test. Asian Australas. J. Anim. Sci. 2003, 16, 1143-1150. [CrossRef]

59. Cronje, P.B. Ruminant Physiology: Digestion, Metabolism, Growth and Reproduction; CABI Publishing: Wallingford, UK, 2000.

60. Jayanegara, A.; Wina, E.; Soliva, C.; Marquardt, S.; Kreuzer, M.; Leiber, F. Dependence of forage quality and methanogenic potential of tropical plants on their phenolic fractions as determined by principal component analysis. Anim. Feed Sci. Technol. 2011, 163, 231-243. [CrossRef]

61. Zhang, S.J.; Chaudhry, A.S.; Osman, A.; Shi, C.Q.; Edwards, G.R.; Dewhurst, R.J.; Cheng, L. Associative effects of ensiling mixtures of sweet sorghum and alfalfa on nutritive value, fermentation and methane characteristics. Anim. Feed Sci. Technol. 2015, 206, 29-38. [CrossRef]

62. Mehrez, A.; Ørskov, E.; McDonald, I. Rates of rumen fermentation in relation to ammonia concentration. Br. J. Nutr. 1977, 38, 437-443. [CrossRef] [PubMed]

63. Satter, L.; Slyter, L. Effect of ammonia concentration on rumen microbial protein production in vitro. Br. J Nutr. 1974, 32, 199-208. [CrossRef] [PubMed]

64. Wang, D.; Fang, J.; Xing, F.; Yang, L. Alfalfa as a supplement of dried cornstalk diets: Associative effects on intake, digestibility, nitrogen metabolisation, rumen environment and hematological parameters in sheep. Livest. Sci. 2008, 113, 87-97. [CrossRef]

65. Eun, J.S.; Beauchemin, K.; Schulze, H. Use of exogenous fibrolytic enzymes to enhance in vitro fermentation of alfalfa hay and corn silage. J. Dairy Sci. 2007, 90, 1440-1451. [CrossRef]

(C) 2019 by the authors. Licensee MDPI, Basel, Switzerland. This article is an open access article distributed under the terms and conditions of the Creative Commons Attribution (CC BY) license (http://creativecommons.org/licenses/by/4.0/). 